\title{
PROTOTIPE SISTEM INFORMASI CUSTOMER RELATION MANAGEMENT BERBASIS WEBSITE STUDI KASUS PT TRI MANDIRI SEJATI
}

\author{
Deasy Purwaningtias, Yoki Firmansyah, Erdian Safitri \\ Universitas Bina Sarana Informatika Kampus Kota Pontianak \\ Jalan Abdurraman saleh No 18 A, Pontianak, Kalimantan Barat \\ e-mail: deasy.dwg@bsi.ac.id
}

\begin{abstract}
Abstrak
PT Tri Mandiri Sejati Pontianak merupakan perusahaan yang bergerak dibidang penjualan motor, suku cadang dan servis motor, berdasarkan observasi dan wawancara yang penulis lakukan banyak ditemukan permasalahan dalam pengolahan data konsumen, terutama pada bagian rekap data konsumen yang kurang baik dan sering menyebabkan kehilangan data penting dan berpengaruh pada menurunnya tingkat pelayanan terhadap pelanggan, oleh karena itu perusahan tersebut membutuhkan sebuah solusi yaitu membuat sebuah perancangan sistem informasi Customer Relation Management yang mana sistem informasi ini diharapkan dapat menyelesaikan permasalahan permasalahan yang ada pada perusahaan, adapun sistem informasi yang dibuat masih berupa prototipe, dalam perancangan sistem informasi ini digunakan metode pengembangan perangkat lunak yaitu metode prototyping, dengan beberapa tahapan yaitu mengenalisa kebutuhan, membuat mock-up dan menguji mock-up, dan yang menjadi dari penelitian ini adalah mendapatkan sebuah rancangan sistem informasi yang dapat mengelola data konsumen, meningkatkan efektivitas dan efisiensi perusahaan khususnya dalam mengelola data konsumen, serta menyelesaikan permasalahan permasalahan yang terjadi khususnya di pengelolaan data konsumen PT Tri Mandiri Sejati Pontianak
\end{abstract}

Kata Kunci: Prototipe, Customen Relation Management, Sistem Informasi

\section{Pendahuluan}

Penerapan atau penggunaan ilmu komputer semakin meluas ke berbagai bidang, seperti bidang geografis, pertanian, pariwisata dan lain sebagainya [1]. Sistem adalah sekumpulan sub sistem, komponen-komponen ataupun element-element yang saling berinteraksi dan bekerja sama dengan tujuan yang sama untuk menghasilkan sebuah hasil yang diinginkan [2]. Sedangkan pendapat lain mengatakan Sistem adalah suatu jaringan kerja yang saling berhubungan antara satu dengan yang lainnya yang berada didalam sistem tersebut untuk mencapai tujuan tertentu yang diinginkan [3]. Tentunya saat ini sistem sudah berkembang yaitu kita mengenal istilah sistem informasi berbasis komputer, Sistem Informasi didefinisikan sebagai suatu alat untuk menyajikan informasi dengan cara sedemikian rupa sehingga bermanfaat bagi penerimanya menurut Kertahadi dalam [4].Mengingat begitu pentingnya sistem untuk mendukung usaha maka dari itu setiap perusahaan wajib menggunakan sistem terutama sistem informasi agar usaha yang dilakukan lebih lancer, dan tercapai efektivitas dan efisiensi, salah satu yang dapat menerapkan sistem informasi untuk mendukung kinerja usahanya adalah PT Tri Mandiri Sejati Pontianak.

PT. Tri Mandiri Sejati adalah suatu perusahaan retail yang bergerak di bidang penjualan sepeda motor dan sparepart motor. Pengolahan data konsumen sangatlah penting untuk meningkatkan penjualan sepada motor dan sparepart motor. PT. Tri Mandiri Sejati merupakan perusahaan yang belum menggunakan sistem yang terkomputerisasi dalam pengolalaan data konsumen untuk setiap pembelian sepeda motor dan sparepart motor. Hal itu dirasakan kurang efektif dan tidak efisien, karena pentingnya pengelolaan data konsumen untuk perusahaan. Selain itu pengelolan data konsumen juga bermanfaat untuk meningkatkan pelayanan yang baik terhadap konsumen. Sedangkan dampak yang ditimbulkan dari masalah tersebut yaitu seringnya terjadi kesalah pahaman informasi yang diberikan kepada konsumen sehingga mengakibatkan kurangnya terjalin hubungan yang baik antara konsumen dan perusahaan. 
Untuk mengatasi masalah tersebut, maka perusahaan PT. Tri Mandiri Sejati membutuhkan suatu bentuk sistem yang dapat memudahkan unit kerja dalam pengelolaan data konsumen yang ada pada PT. Tri Mandiri Sejati agar dapat meningkatkan penjualan sepeda motor dan sparepart motor serta meningkatkan pelayanan perusahaan kepada konsumen.

Adapun sistem informasi yang dapat diterapkan oleh perusahaan merupakan sistem informasi yang berbasis website. Website merupkaan kumpulan halaman yang digunakan untuk menampilkan informasi dalam bentuk teks, gambar diam atau gerak, animasi, suara, dan/gabungan dari semuanya baik bersifat statis maupun dinamis yang membentuk suatu rangakaan yang saling terkait, yang masing masing dihubungan dengan jaringan jaringan halaman[5], website yang sering disingkat dengan web bisa diartikan sebagai sekumpulan halaman yang terdiri dari beberapa laman yang berisikan informasi dalam bentuk digital yang disediakan melalui jalur koneksi internet [6][7].

Yang menjadi tujuan dari penelitian ini adalah terbantunya PT Tri Mandiri Sejati pontianak dalam menjalankan usahanya terkait dengan pengolahan data konsumen, dan mendapatkan kembali kepercayaan konsumen terhadap perusahaan yang selama ini berkurang karena lemahnya pelayanan dari perusahaan,.

\section{Metode penelitian}

Dalam penelitian ini menggunakan metode penelitian berupa eksperimen, dimana penulis melakukan penelitian tentang suatu permasalahan, kemudian mengamati prosesnya serta menuliskan hasil penelitiannya, selanjutnya adapula metode pengembangan perangkat lunak, dan metode pengumpulan data

\subsection{Metode Pengembangan Perangkat Lunak}

Untuk mengembangkan system informasi Customer Relation Management ini penulis mengugunakan salah satu model dari pengembangan perangkat lunak yaitu model prototype. Model prototype adalah suatu model yang dapat digunakan untuk mensimulasikan suatu program yang disajikan oleh pihak developer kepada pelanggan agar pelanggan lebih memahami dan memilih program yang cocok untuk digunakan oleh pelanggan. Model prototipe dapat digunakan untuk menyambung ketidakpahaman pelanggan mengenai hal teknis dan memperjelas spesifikasi kebutuhan yang diinginkan pelanggan kepada pengembang perangkat lunak. diuraikan sebagai berikut:

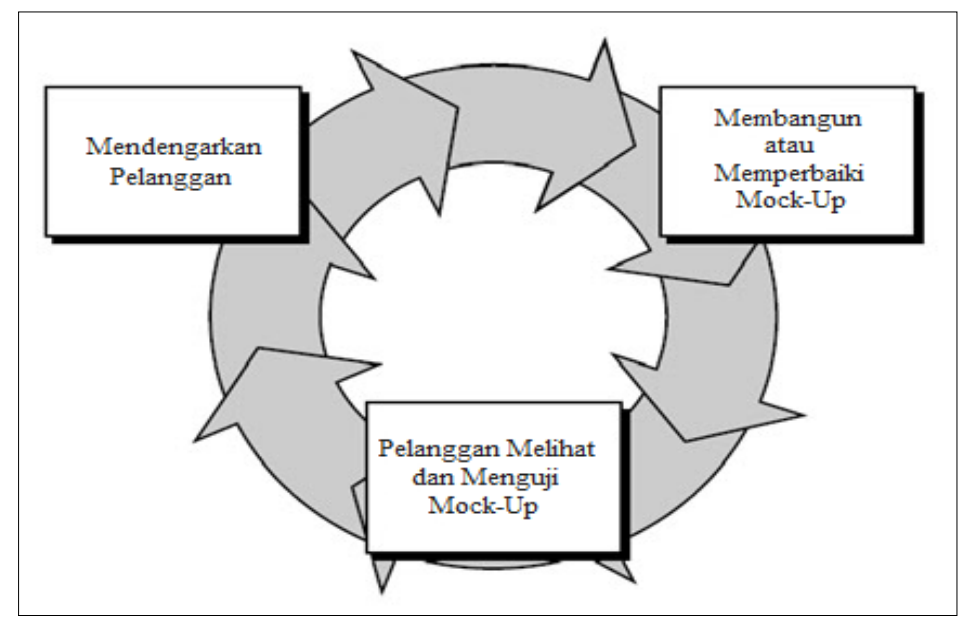

Gambar 1. Ilustrasi Model Prototype[8]

a. Mendengarkan Pelanggan

Tahap pertama ini dilakukan untuk mendengarkan keluhan serta harapan dari pelanggan, dimana yang dimaksud dengan pelanggan dalam penelitian ini adalah PT Tri Mandiri Sejati Pontianak, disini penulis melakukan wawancara kepada pimpinan perusahaan, dan dari sini penulis menemukan permasalahan permasalahan yang penulis angkat pada bagian pendahuluan, dari permasalahan tersebut lah penulis olah dan menjadi sebuah solusi yaitu membuat sebuah prototipe sistem informasi yang 
dapat dimanfaatkan oleh perusahaan dalam menyelesaikan permasalahan permasalahan yang terjadi

b. Membangun Mockup

Setelah permasalahan ditemukan, dan keinginan dari pelanggan didapatkan maka berikutnya adalah tahap membangun mockup, yang dimaksd dengan mockup adalah rancangan atau desain dari prototype, mulai dari rancangan data base yang dituangkan di dalam Logical Relations Structure (LRS) serta Entity Relation Diagram (ERD), hingga rancangngan dari tampilan system informasi yang akan dibuat, sehingga akan mempermudah programmer apabila akan menerapkan prototipe system informasi ini

c. Menguji Program

Setelah di buat rancangan maka berikutnya rancangan diterapkan kedalam pembuatan program, namun karena penelitian ini hanya berfokus pada prototipe system informasi saja maka dari itu tidak sampai pada tahap pengujian program

\subsection{Metode Pengumpulan Data}

Selain menggunakan metode pengembangan perangkat lunak penulis juga menggunakan teknik pengumpulan data, adapun penjelasan dan tahapan dari pengumpulan data dijelaskan sebagai berikut :

a. Observasi

Pada tahapan ini, penulis melakukan observasi secara langsung pada PT Tri Mandiri Sejati Pontianak bagaimana selama ini karyawan melayani pelanggan, dan melihat beberapa fenomena yang ada pada objek penelitian, dan hasilnya adalah penulis menemukan permasalahan permasalahan yang sudah penulis tulis sebelumnya, dan dari observasi ini pula penulis menyimpulkan bahwa perusahaan membutuhkan sebuah sistem informasi berbasis komputer untuk menyelesaikan permasalahan permasalahan tersebut

b. Wawancara

Setelah menemukan permasalahan yang ada pada tahap observasi berikutnya penulis melakukan wawancara kepada karyawan ataupun pimpinan dari perusahan, hal ini dilakukan untuk mencari solusi dan mendengarkan kebutuhan dari perusahaan terkait sistem informasi yang akan dibuat,

c. Studi Pustaka

Penulis melakukan suatu metode pengumpulan data dengan cara membaca literatur yang berkaitan dengan penelitian. Literatur didapatkan dari bermacam sumber seperti buku literatur maupun jurnal jurnal dan paper terbitan terbaru yaitu 5 - 10 tahun terakhir untuk menjaga literatur yang diergunakan masih relevan dengan penelitian yang dijalankan

\section{Hasil dan Analisis}

Setelah melakukan observasi dan wawancara maka didapatlah bahwa permasalahan yang terjadi selama ini di PT Tri Mandiri Sejati Pontianak adalah belum adanya sebuah sistem informasi yang baik untuk menunjang perusahan khususnya terkait permasalahan konsumen, maka dari itu hasil dari penelitian ini merupakan sebuah rancangan atau prototipe sistem informasi Customer Relation Management adapun tahapan dalam menemukan permasalahan dituangkan menggunakan metode prototyping yang dijabarkan sebagai berikut

\subsection{Mendengarkan Kebutuhan Pelanggan}

Seperti yang diketahui sebelumnya bahwa tahap pertama dari Metode prorotyping adalah mendengarkan kebutuhan pelanggan, dari hasil wawancara akhirnya ditemukan bahwa yang menjadi keinginan perusahaan adalah berubahnya sistem adapun yang menjadi usulan dari penulis untuk perusahaan adalah sebagai berikut : 
a. Penjualan

- Penjualan Sepeda Motor

Sales menyiapkan beberapa berkas untuk melakukan penjualan seperti SPK dan CDB setiap ingin melakukan penjualan. Sales mengisi SPK dan CDB berdasarkan data yang diberikan oleh konsumen. Setelah itu sales memberikan SPK dan CDB ke supervisor marketing untuk proses pengecekan sebelum diserahkan kepada admin penjualan. Selain itu supervisor marketing juga melakukan perekapan data konsumen di laporan harian sales (LHS). Setelah proses pengecekan dan perekapan data konsumen selesai supervisor marketing memberikan SPK yang sudah di tanda tangani oleh supervisor marketing kepada admin penjualan untuk dimasukkan ke dalam sistem.

- Servis Sepeda Motor dan Suku Cadang Sepeda Motor

Setiap Konsumen yang ingin melakukan servis dan pembelian suku cadang sepeda motor konsumen menyerahkan beberapa berkas seperti Surat Tanda Nomor Kendaraan (STNK) kepada admin bengkel untuk di isi pada Form Service Advisor (FSA). Dalam FSA tersebut terdapat data konsumen dan data sepeda motor konsumen dan di dalam FSA tersebut juga terdapat rincian servis dan penggantian suku cadang sepeda motor jika ada. Setelah admin bengkel mengisikan FSA tersebut dengan sesuai admin bengkel menyerahkan kepada admin penjualan untuk dimasukkan data konsumen ke sistem

b. Pengelolaan Data

- Data Penjualan Sepeda Motor

SPK dan CDB dari sales yang telah diterima oleh admin penjualan akan dimasukkan datanya dalam basis data penjualan sepeda motor. Kemudian admin penjualan membuat laporan data penjualan sepeda motor (DPM) sebagai bahan dalam proses penjualan silang.

- Data Servis dan Penjualan Suku Cadang Sepeda Motor

FSA yang diterima oleh admin penjualan kemudian dimasukkan ke dalam basis data servis dan penjualan suku cadang sepeda motor (DSM). Dari data tersebut dapat dijadikan bahan dalam proses penjualan silang.

c. Penjualan Silang (Crosselling)

- Data penjualan sepeda motor (DPM) bulan sebelumnya yang sudah disiapkan admin penjualan seterusnya diberikan kepada admin bengkel untuk dihubungi kembali dan diingatkan kembali untuk melakukan servis. Setelah itu admin bengkel membuat laporan hasil dari data penjualan sepeda motor (LDPM) bulan lalu yang sudah melakukan servis sepeda motor dan diberikan kepada admin penjualan.

- Data servis dan penjualan suku cadang sepeda motor (DSM) bulan sebelumnya yang sudah disiapkan admin penjualan seterusnya diberikan kepada supervisor marketing untuk dihubungi kembali dan melakukan promosi kepada konsumen. Setelah itu supervisor marketing memberikan laporan hasil dari data servis dan penjualan suku cadang sepeda motor (LDSM) bulan lalu yang telah membeli sepeda motor dan diberikan kepada admin penjualan.

d. Laporan

Dari laporan yang diterima oleh admin bengkel dan sales maka admin penjualan dapat membuat laporan hasil penjualan silang setiap bulannya. Laporan penjualan silang diperiksa terlebih dahulu oleh kepala admin sebelum diserahkan kepada kepala cabang.

\subsection{Membangun Mock up}

Setelah mengetahui kebutuhan dari pelanggan, maka berikutnya adalah membangun mockup, dalam tahap ini penulis menggambarkan prosedur prosedur yang ada diatas kedalam desain sistem yang akan diusulkan kepada perusahaan, seperti desain DAD, ERD, LRS, serta rancangan struktur naviagasi dari sistem informasi yang akan dibuat, adapun masing masing penjelasan dari desain tersebut adalah sebagai berikut :

- Diagram Alir Data

Adapun sistem usulan yang dirancang oleh penulis akan digambarkan ke dalam bentuk diagram alir data (DAD) sistem usulan yang bertujuan menggambarkan alur data secara garis besar. Adapun bentuk diagram alir data (DAD) sistem usulan pada PT. Tri Mandir Sejati Pontianak terdiri dari diagram konteks sistem usulan, diagram nol sistem usulan dan diagram detail sistem usulan yang dapat dilihat di bawah ini. 


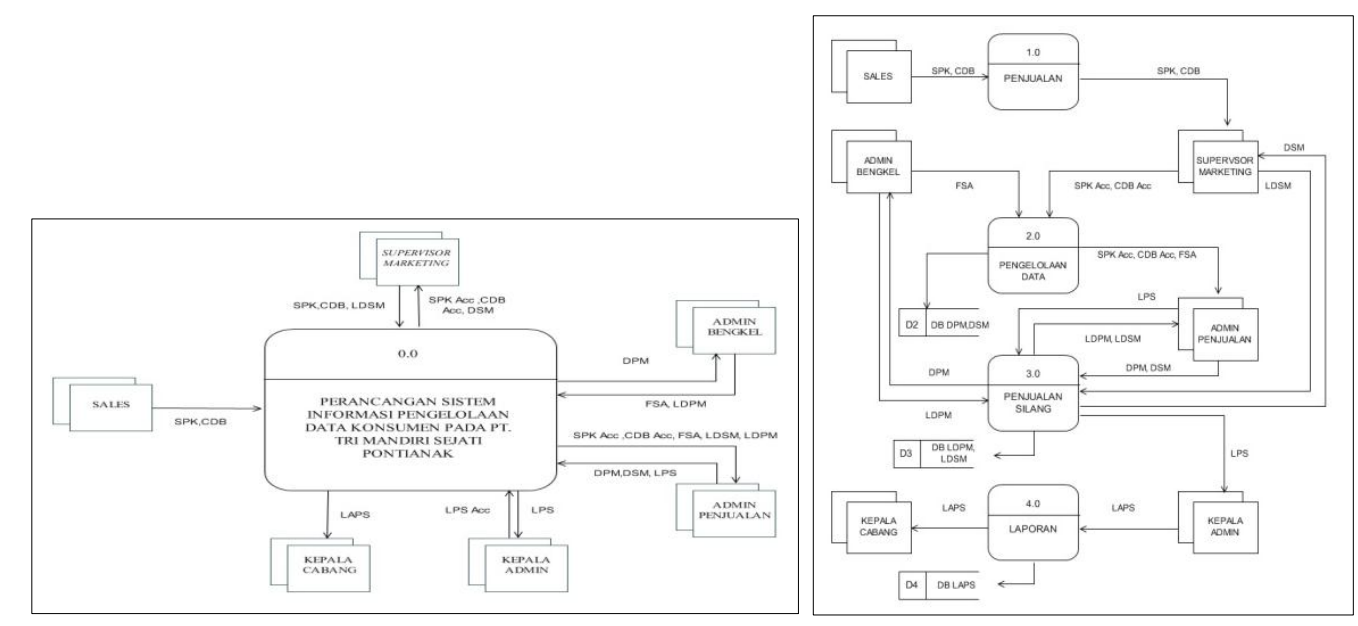

Gambar 2. Diagram Konteks Sistem Usulan

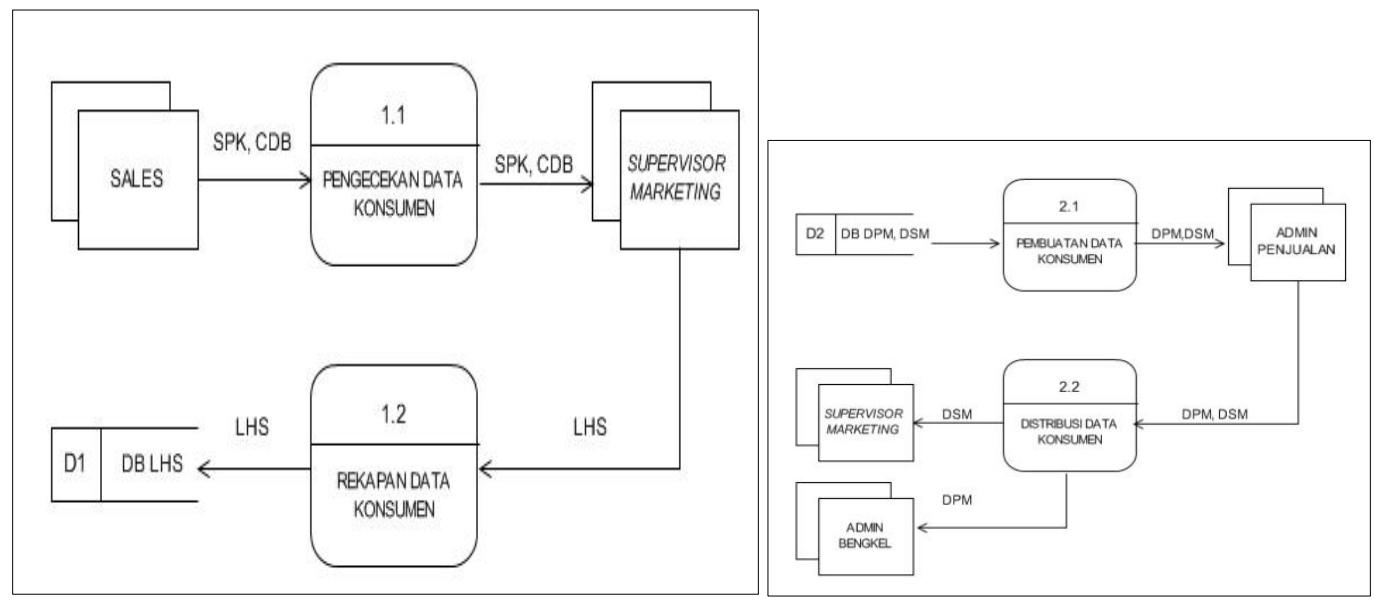

Gambar 3. Diagram Nol Sistem Usulan

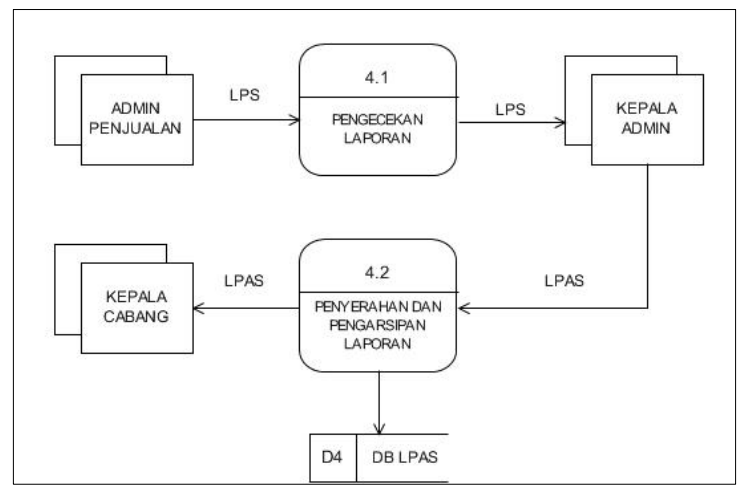

Gambar 6. Diagram Detail 3 Sistem Usulan 
- Struktur Navigasi Sistem Usulan

Struktur Navigasi Admin Penjualan dan Kepala Admin
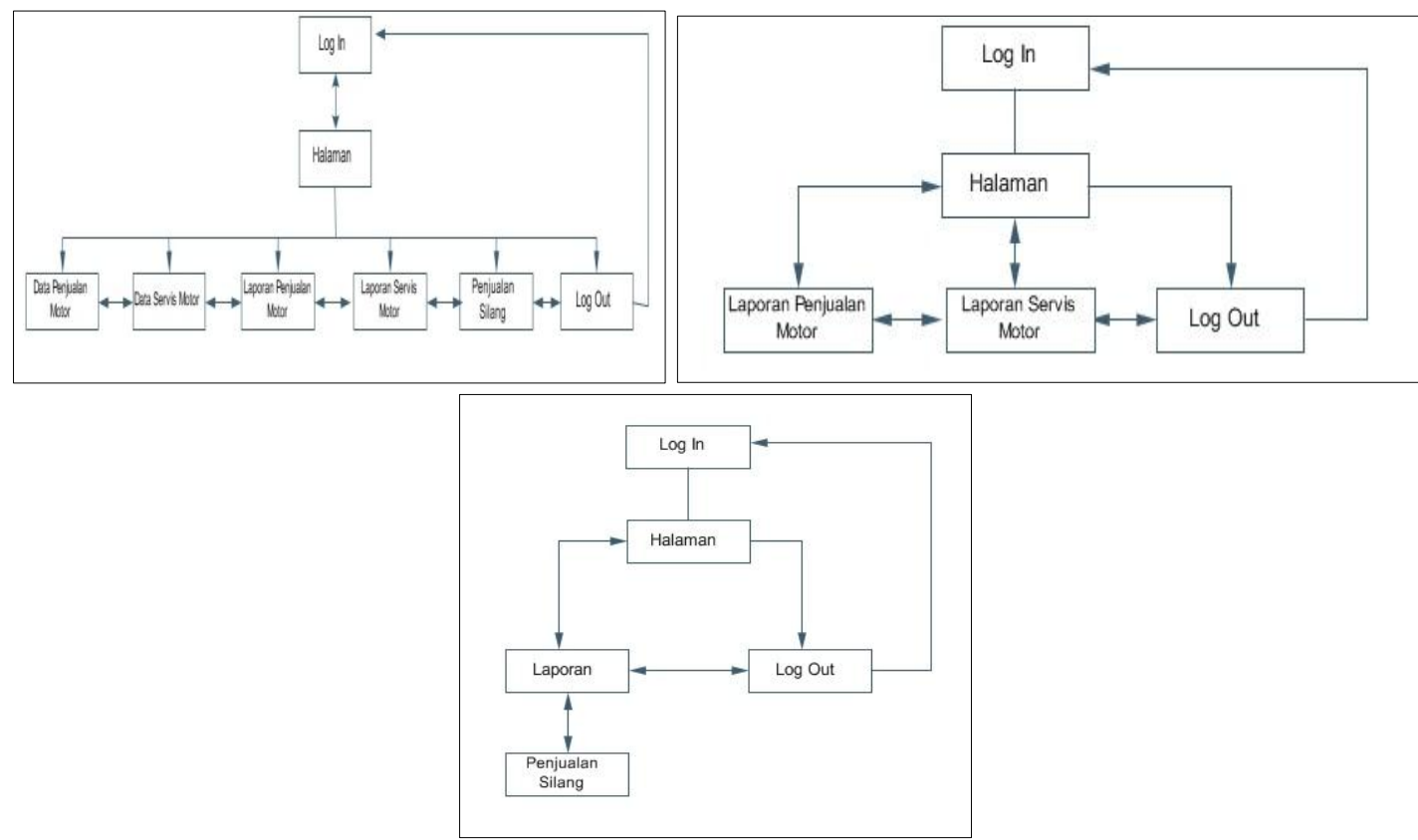

\section{Gambar 7. Struktur Navigasi Sistem Informasi}

\section{ERD dan LRS}

Entity relationship diagram (ERD) merupakan bagian dari tahapan perancangan sistem yang menjelaskan hubungan antara basis data terkait. Hasil dari entity relationship diagram (ERD) yang dirancang kemudian ditampilkan ke dalam bentuk logical record structure (LRS) agar memberikan gambaran lebih jelas terhadap basis data yang dirancang oleh penulis. Adapun logical record structure (LRS) yang dirancang oleh penulis yaitu:
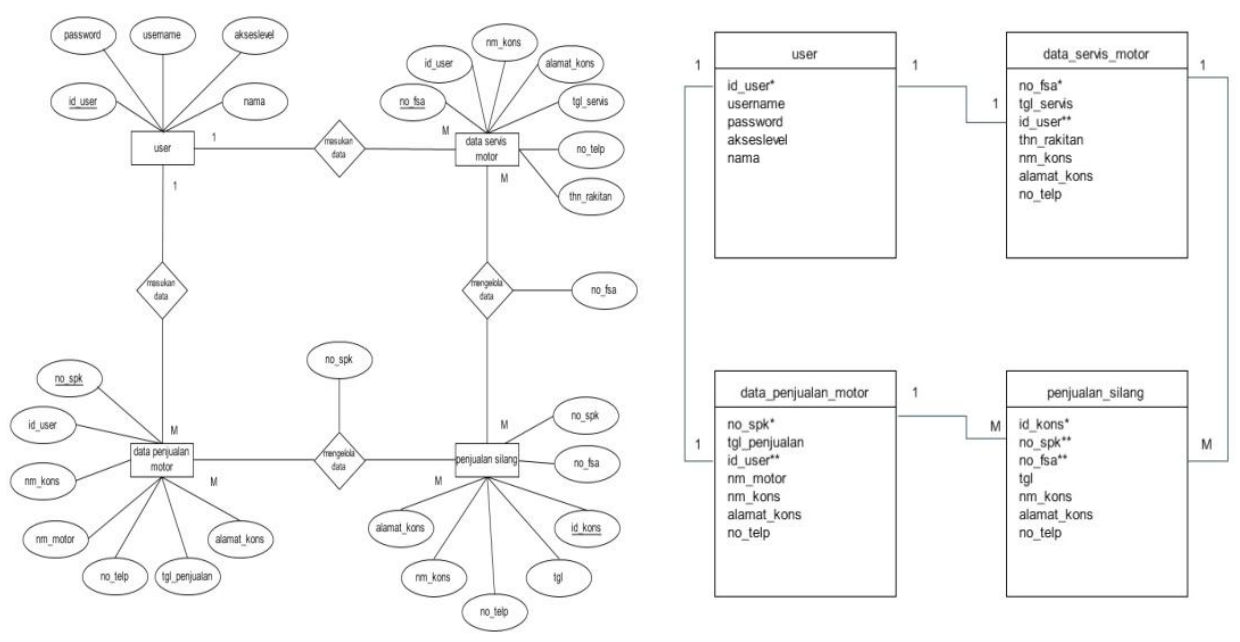

Gambar 10. ERD dan LRS Sistem Informasi 
- Mock up Tampilan Aplikasi

Tampilan Menu Login

\section{TRI MANDIRI SEJATI}

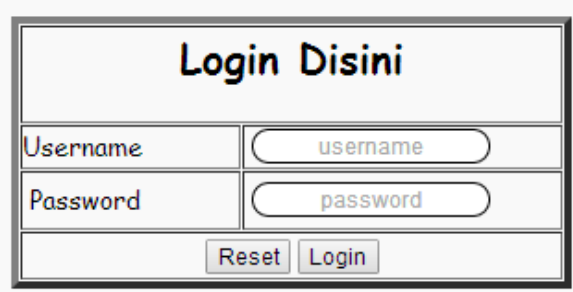

Gambar 12. Mock Up Menu Login

Tampilan Menu Utama

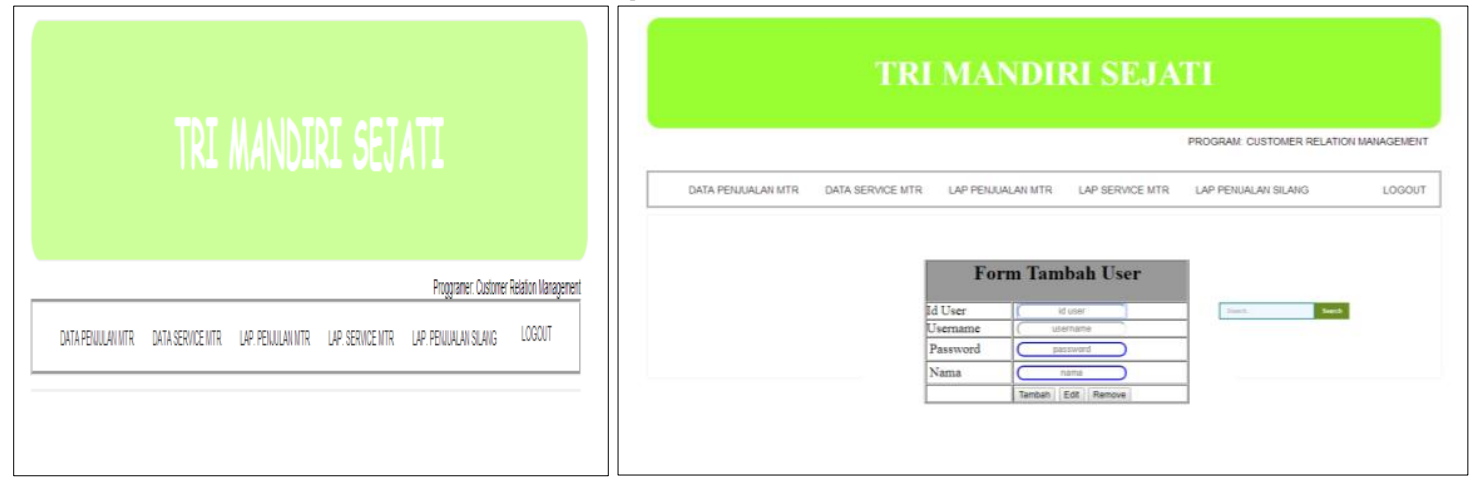

Gambar 13. Mockup Tampilan menu Utama Dan Menu User

Tampilan Menu Data Konsumen Penjualan

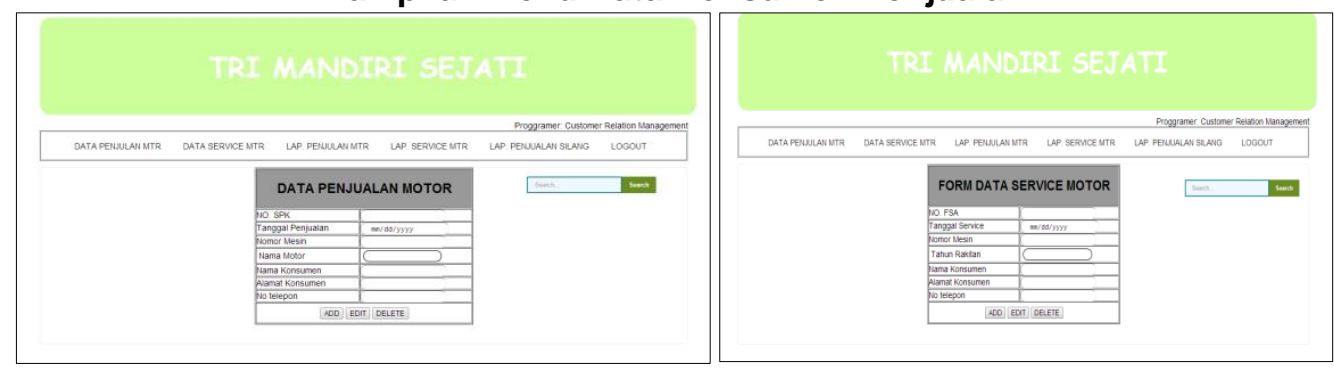

Gambar 15. Mock Up Tampilam Menu Data Konsumen servis

Tampilan Menu Laporan Penjualan Motor 


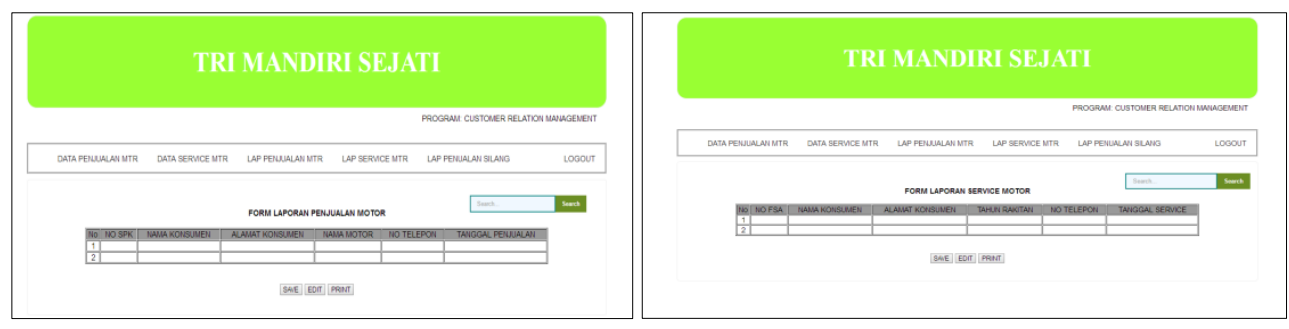

Gambar 17. Mockup Menu Laporan Penjualan Motor

\section{Kesimpulan}

Setelah dilakukan analisa dan pembahasan seperti yang di paparkan pada bagian sebelumnya maka dapat ditarik beberapa kesimpulan diantaranya adalah sistem yang selama ini diterapkan pada perusahaan belum terkomputerisasi secara maksimal, sehingga data konsumen yang ada belum digunakan secara maksimal juga, dan data konsumen yang ada hanya disimpan dan tidak diolah kembali berikutnya dengan adanya sistem pengeolalaan data konsumen yang telah terkomputerisasi maka diharapkan dapat membantu dan mempercepat proses kerja dari perusahaan sehingga tercipta efektifitas dan efisienssi kerja dan pastinya akan meningkatkan produktifitas SDM dan penjualan, dan pelayanan konsumen akan menjadi lebih baik.

Sistem yang dirancang tidak hanya bisa mengolah data saja melainkan juga dapat menghasilkan laporan, seperti laporan penjualan data motor, laporan data servis, dan laporan penjualan silang, sehingga menghasilkan informasi yang dapt digunakan oleh pimpinan perusahaan dalam melakukan pengambilan keputusan,

\section{Pengakuan dan Penghargaan}

Ucapan terima kasih penulis sampaikan kepada pihak perusahaan yaitu PT Tri Mandiri Sejati Pontianak dan kepada universitas bina sarana informatika kampus kota pontianak yang telah memberikan sumbangsi nya kepada penulis dalam menyelesaikan penelitian ini

\section{References}

[1] A. Nurhadi, E. Indrayuni, and A. Sinnun, "Perancangan Website Sistem Informasi Penjualan Kamera," Peranc. Website Sist. Inf. Penjualan Kamera, pp. 205-213, 2015.

[2] S. Mulyani, Sistem Informasi Manajemen. Bandung: Abdi Sistematika, 2016.

[3] J. Hutahaean, Konsep Sistem Informasi. Yogyakarta: CV. Budi Utama, 2015.

[4] D. Risdiansyah, "Perancangan Sistem Informasi Bimbingan Konseling Berbasis Desktop pada SMA Kemala Bhayangkari 1 Kubu Raya Deni," Khatulistiwa Inform., vol. 5, no. 2, pp. 86-91, 2017.

[5] A. baitul Hikmah, D. Supriadi, and Bina Sarana Informatika, Cara Cepat Membangun Website dari Nol: Studi Kasus : Web Dealer Motor. Yogyakarta: CV. Andi Offset, 2015.

[6] R. Abdulloh, Easy \& Simple - Web Programming. Jakarta: Elex Media Computindo, 2016.

[7] Y. Firmansyah and Pitriani, "Penerapan Metode SDLC Waterfall Dalam Pembuatan Aplikasi Pelayanan Anggota Pada CU Duta Usaha Bersama Pontianak," J. Bianglala Inform., vol. 5, no. 2, pp. 66-74, 2017.

[8] R. A. Sukamto and M. Shalahuddin, Kolaborasi Rekayasa Perangkat Lunak Terstruktur dan Berorientasi Objek. Bandung: Informatika, 2015. 


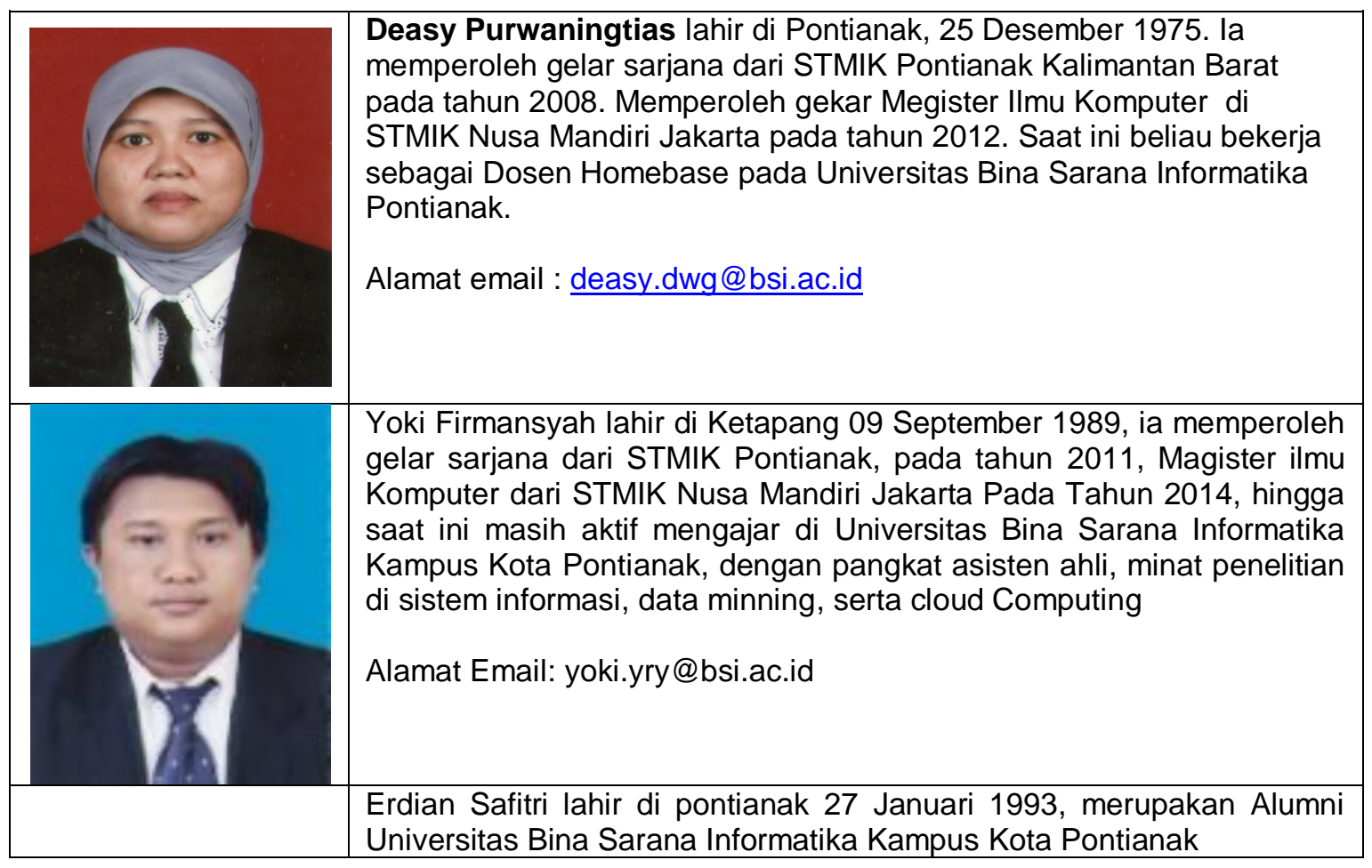

